good, in fact the neck was now so much twisted that she had to stand sideways-off side against the crib-to get her head in. The neck appeared slightly enlarged over the last three cervical vertebræ, where it was turned sharply round to the off side, and altogether it was much like what is seen in cows down in milk fever, only that the twist in this case was quite close to the anterior part of the chest, and the neck could not be extended into a straight line with ordinary force. She had not lain down that day.

Monday.-Pulse 50, temperature $100^{\circ}{ }^{\circ} \mathrm{F}$, respirations slightly accelerated, very slight protrusion of the haw and erection of the tail, hind legs stuck out, abdomen tucked up, occasional muscular spasms, causing animal to nearly fall, appeared fully sensible and followed round the box, but always bearing to the off side, head and neck much more bent, in fact more than half-way round to the off side of the chest. She could turn the head half round on the neck, but could not move the neck, which appeared fixed as if dislocated at its lower third; the muscles did not appear to be in any spasm on either side. The movements of the jaw were quite natural. The mare could pick and grind her food as if nothing the matter, and during the early part of the day she ate freely, but later she ate very little. The cedema was still more extensive between the fore legs, bowels acting fairly often, and fæces of nice consistence but slightly coated with mucus.

Monday Evening.-After eagerly drinking some chilled water from a pail held up to her head the mare was seized with a violent muscular spasm, which caused her to fall, and from this time all power of maintaining the normal position was lost. Whilst lying on the near side she was constantly struggling, and she was therefore shot.

Post-mortem.- - On removing the skin it was found that all the œdematous parts were of a dirty reddish-grey colour, and had a most offensive odour. It appeared as if the subscapular tissues and muscles had been torn from the force of the blow on the surfaces of the ribs, after the shaft, which was that of a heavy spring cart, had entered the slin. The wound was about 2 inches wide, and ran upwards and backwards to the spine, where three ribs were broken off just below their heads, viz., the fourth, fifth, and sixth. The fifth dorsal vertebra was fractured and slightly displaced, and there was some discolouration on the inside of the chest under the fractured ribs and vertebra, but the pleura did not appear lacerated.

\title{
A CASE OF FRACTURE OF THE FEMUR IN AN ELEPHANT, SUCCESSFULLY TREATED.
}

\section{By T. F. Stanton, D.V.A., Veterinary Surgeon to the Barnum and Bailey Show.}

THE subject of this note was a young elephant belonging to Messrs Barnum and Bailey's Show. On 28th May I897, the elephant fell while being unloaded from the cars at Clarksville, Tennessee, U.S.A. As she could not rise she was placed in a tarpaulin and carried by the men to the lot, a distance of half a mile or more, before I examined her, and was none too carefully handled. She was then conveyed on 
a dray to ny infirmary and placed in a sling, but at the end of five days I had to lower her on to the ground. She refused to stand on the uninjured leg and was doubled up in the sling, had stopped eating and would have died had she remained in the sling. For the next five weeks she was lowered on to the ground every night and raised again in the morning, and kept in the sling during the day. In six weeks she could stand on the injured leg. but I kept her in the sling every day, lowering her to the ground at night for another six weeks, and then sent her home. There was very little deformity or shortening of the injured limb (the femur shows $I \frac{1}{2}$ inches shortening by actual measurement). The elephant had such perfect use of the limb, that, upon arrival at New York, two prominent veterinarians of that city who examined her reported to $\mathrm{Mr}$ Bailey that the femur had never been fractured.

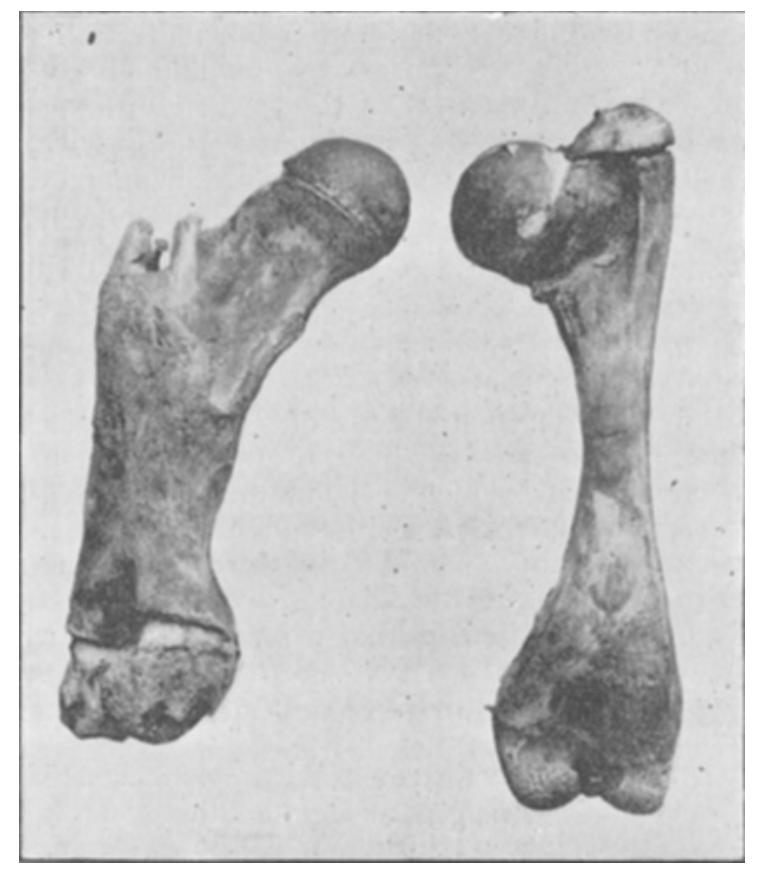

The animal was destroyed at Olympia, London, I8th March r898, because of repeated attacks of rheumatism, which effected both fore legs. The broken leg was never affected. The accompanying illustration reproduces a photograph of the animal's thigh bones.

The interesting features of this case are, (I) that the animal was carried over rough ground in a tarpaulin for over half a mile, and rather roughly handled before any attempt was made to reduce the fracture; (2) that it was impossible to keep her in a sling while the repair of the bone was in progress; and (3) that no splints of any kind were used, the limb being kept in position by leather straps alone.

As our lecturer on surgery in college pronounced this fracture incurable, and as Professor Williams expresses a similar opinion in his work on surgery, 1 thought the case was worth reporting. 